\title{
THE NATIONAL ENERgY BOARD'S PARTICIPATION FRAMEWORK: IMPLEMENTING CHANGES RESULTING FROM THE JOBS, GROWTH AND LONG-TERM PROSPERITY ACT
}

\author{
JODY SAUNDERS AND JESSICA LIM*
}

As a result of the enactment of the Jobs, Growth and Long-term Prosperity Act, the National Energy Board was required to change its processes relating to standing and level of participation. The Board developed and implemented a Participation Framework to provide clear and consistent guidance to the public on how the Board implemented the changes in the amending legislation. This article delineates the evolution of the Board's approach to participation and discusses how the Board has responded to larger and increasingly complex projects as it carries out its mandate in the Canadian public interest.
En conséquence de l'adoption de la Loi sur l'emploi, la croissance et la prospérité durable, l'Office national de l'énergie a dû modifier ses méthodes relatives à la participation de longue date et le degré de celle-ci. L'Office a préparé et mis en œuvre un cadre de travail pour la participation du public dans le but de fournir à celui-ci une direction claire et constante sur la manière dont l'Office met en œuvre les changements apportés par la loi amendée. Cet article présente l'évolution de la démarche de l'Office quant à cette participation et traite de la manière dont l'Office a réagi à des projets plus importants et de plus en plus complexes dans le cadre de son mandat dans l'intérêt public des Canadiens.

\section{TABLE OF CONTENTS}

I. IntRODUCTION ....................................... 366

A. Distinction BETWEen STANDING AND

LEVEl of PARTICIPATION . .......................... 367

II. THE DEVELOPMENT OF THE BOARD'S

PARTICIPATION FRAMEWORK . . . . . . . . . . . . . . . . . . . 368

A. CONSIDERATIONS UNDERPINNING THE

BOARD's NEW PARTICIPATION FRAMEWORK . . . . . . . . . . . 368

B. The Statutory StAnding Test — Section $55.2 \ldots \ldots \ldots \ldots . . \ldots 373$

C. Non-Legislated Test - What Test Should be

APPLIED FOR ALL OTHER APPLICATIONS? . . . . . . . . . . . . . . . . . . . 377

D. LEVEL OF PARTICIPATION . . . . . . . . . . . . . . . . . . . . . . . . 379

E. BURDEN OF PROOF ............................. 381

III. IMPLEMENTATION OF THE BOARD'S

PARTICIPATION FRAMEWORK . . . . . . . . . . . . . . . . . . . . . 382

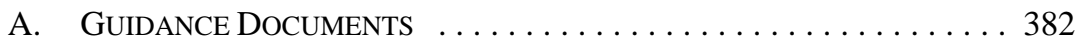

B. APPLICATION TO PARTICIPATE FoRM $\ldots \ldots \ldots \ldots \ldots \ldots \ldots . \ldots . \ldots . \ldots 382$

C. Participation in RECEnt BoARd ProceEdings . . . . . . . . . . . . . 382

D. Court Challenges and Reviews $\ldots \ldots \ldots \ldots \ldots \ldots \ldots \ldots$

IV. COnCLUSION $\ldots \ldots \ldots \ldots \ldots \ldots \ldots \ldots \ldots \ldots \ldots \ldots \ldots \ldots \ldots$

Jody Saunders is Professional Leader, Legal at the National Energy Board, and has been practicing regulatory law with the Board since 2001. Prior to that, she practiced at the corporate and commercial litigation law firm, Duncan McCachen Code. Jessica Lim has been legal counsel with the Board since 2011, and was previously practicing regulatory law with Osler, Hoskin and Harcourt LLP. The views expressed by the authors in this article and in the presentation are those of the authors and not the Board. 


\section{INTRODUCTION}

The National Energy Board's (Board or NEB) default threshold or bar for granting standing was developed over a period of time when interest from the Canadian public, both in terms of pipeline issues and, more broadly, energy policy, was often low. Typically fewer than 30 interested parties sought intervenor status from the Board, ${ }^{1}$ and in many cases the number of active intervenors in the oral portion of a facilities hearing did not exceed the low double digits. $^{2}$

Prior to amendments in 2012, section 53 of the National Energy Board Act ${ }^{3}$ stated: “[o]n an application for a certificate, the Board shall consider the objections of any interested person, and the decision of the Board as to whether a person is or is not an interested person for the purpose of this section is conclusive."

In applying this section, the Board typically allowed all persons who were interested in a proposed project the opportunity to participate at the level requested, whether that was the fullest level of participation (as an intervenor) or a reduced level (a written letter of comment).

In 2012, through the Jobs, Growth and Long-term Prosperity Act, ${ }^{5}$ Parliament amended the provisions regarding standing for certificate applications. Section 55.2 of the NEB Act currently states:

On an application for a certificate, the Board shall consider the representations of any person who, in the Board's opinion, is directly affected by the granting or refusing of the application, and it may consider the

For example, in the TransCanada Keystone Pipeline OH-1-2007 proceeding, there were 33 people granted intervenor status, five letter of comment writers, and three government participants; at the oral portion of the hearing, only 10 parties registered an appearance (TransCanada Keystone Pipeline GP Ltd (September 2007), OH-1-2007, online: NEB < www.neb-one.gc.ca >). The subsequent TransCanada Keystone XL OH-1-2009 proceeding had similar numbers: 29 people granted intervenor status, with 12 registering their appearance during the oral portion of the hearing and nine letters of comment (TransCanada Keystone Pipeline GP Ltd (March 2010), OH-1-2009, online: NEB <www.neb-one. gc.ca>).

2 Of course, there are notable exceptions. For example, in the Sable Offshore Energy/M\&NP GH-6-96 Joint Panel Review proceeding, 67 intervenors registered an appearance (Sable Offshore Energy Project (December 1997), GH-6-96, online: NEB < www.neb-one.gc.ca>). In the Alliance GH-3-97 proceeding, more than 70 intervenors registered an appearance at the hearings (more than 115 applied for and received intervenor status), and an additional 42 people provided letters of comment or specialist advice (Alliance Pipeline Ltd on behalf of the Alliance Pipeline Limited Partnership (November 1998), GH-397, online: NEB < www.neb-one.gc.ca>). In the Sumas Energy 2, Inc. EH-1-2000 proceeding, over 400 people were granted intervenor status, 207 registered an appearance, more than 400 attended the first day of the hearing and over 90 of those intervenors actively participated in the 2001 portion of the hearing (subsequent to this portion, Sumas Energy 2 requested an adjournment to the EH-1-2000 proceeding). In the 2003 portion of the EH-1-2000 proceeding, approximately 30 intervenors crossexamined panels, 28 gave oral presentations and 88 provided oral final argument. Throughout the EH-12000 proceeding, 22,000 letters of comment were received (Sumas Energy 2, Inc (March 2004), EH-12000, online: NEB <www.neb-one.gc.ca> [Sumas Energy 2]). In the Northern Gateway OH-4-2011 Joint Review Panel process, more than 200 people were granted intervenor status (although only approximately 50 were active beyond the initial filing of written evidence), oral evidence was presented by over 390 people, there were 12 government participants, and more than 1,170 oral statements and 9,000 letters of comment (NEB, Considerations: Report of the Joint Review Panel for the Enbridge Northern Gateway Project, vol 1 (Calgary: NEB, 2013) at 4).

RSC 1985, c N-7 [NEB Act].

Ibid as it appeared in July 2012 [emphasis added].

SC 2012, c 19 [Jobs Act]. 
representations of any person who, in its opinion, has relevant information or expertise. A decision of the Board as to whether it will consider the representations of any person is conclusive. ${ }^{6}$

By enacting section 55.2, Parliament created two ways by which a person could seek to gain standing in a Board hearing on an application for a certificate to construct and operate a facility: (1) by demonstrating that they are directly affected by the project, and (2) by providing relevant information or expertise. Those people who are directly affected must be given standing, while the Board has discretion to give standing to those people who have relevant information or expertise. For ease of reference, this article refers to these ways or means of obtaining standing as "categories."

While Parliament established the standing test, with its attendant categories, it did not provide guidance to the Board on how to implement this test. This article explains how the Board developed and implemented a consistent and legally sound approach to participation, not just for certificate applications, but for all applications under the NEB Act for which a written or oral hearing is held (the Participation Framework).

\section{A. Distinction BetWEen STANDing AND LEVEL OF PARTICIPATION}

When discussing standing, often there can be some confusion between the concepts of "standing" and "level of participation." These are two different concepts that are sometimes spoken of interchangeably, perhaps due in part to their arising around the same time in a proceeding and their common reliance on principles of natural justice and procedural fairness. $^{7}$

Standing includes all levels of participation, and not just full participation as an intervenor. While standing tests determine whether a person ought to be allowed to participate, they do not necessarily dictate the level of participation that should be granted or offered. That determination may turn on statutory or natural justice considerations or be a discretionary decision based on any number of factors, including practical or logistical ones. In this article, "standing" refers to the ability to participate, in any manner, before the Board, whereas "level

Supra note 3, s 55.2 [emphasis added].

In the Sumas Energy 2, Reasons for Decision, supra note 2 at 6, the Board described the principles of natural justice and fairness as follows:

the content of the principles of natural justice and fairness will vary from case to case. Essentially, what is "fair" requires a balance between what is necessary for the effective and efficient performance of public duties, as mandated under an empowering statute, and what is necessary for the protection of the interests of the parties affected.

Generally, there are two components to the principles of natural justice and fairness. First, a party must have an adequate opportunity to be heard before a decision is made affecting that party's interest. The second component is that the decision must be made by an independent decisionmaker [footnotes omitted].

For the purposes of this article, the spectrum of procedural fairness and natural justice requirements is referred to as "principles of natural justice." The content of these principles will be factually derived and their application case specific. As a result, the procedural protections required in each case may fall along different points of the spectrum. 
of participation" refers to how someone can participate, ${ }^{8}$ as opposed to whether the person ought to be allowed to participate.

In the past, the Board did not typically need to distinguish between the two concepts when making the initial "who can participate and how" decision at the beginning of an application assessment process. Historically, due to the lack of specificity of the phrase "interested person" and the absence of a need to interpret this phrase more strictly, the test for standing was interpreted and applied liberally at the Board. When a person filed an application to intervene, the Board generally allowed the person in, making an implicit decision that the person had both standing and his or her interest justified participation at the highest level. This liberal interpretation resulted in most people being granted standing at the level requested. Prior to the Jobs Act, the Board typically addressed standing and level of participation when a person sought late intervenor status or when there was an objection to the participation of a person.

Both standing and level of participation will be discussed in this article, although the focus is on standing.

\section{THE DEVELOPMENT OF THE BOARD'S PARTICIPATION FRAMEWORK}

\section{A. CONSIDERATIONS UNDERPINNING THE BOARD'S NEW PARTICIPATION FRAMEWORK}

\section{PurPose OF GRANTING STANDING AT THE NEB}

When devising the framework for participation, and in particular for standing, the Board's starting point was to look at the purpose of granting standing. What goal was standing at the Board meant to achieve?

Standing has one general function: to allow people the opportunity to be heard by the decision-maker prior to a decision being made. Generally (subject to legislative restrictions), the principles of natural justice require a person to be heard when that person could be impacted by the decision. ${ }^{9}$ This legal entitlement to be heard may be reflected in legislation. However, even if legislation is silent, standing to be heard due to potential impact is required by the common law, through the application of the principles of natural justice by which quasi-judicial administrative tribunals, such as the Board, are bound. ${ }^{10}$

That is, what "bucket" of participatory rights and responsibilities they have (for example, the full intervenor rights and responsibilities or the reduced rights and responsibilities of a writer of a letter of comment).

$9 \quad$ Sumas Energy 2, supra note 2 at 6.

10 While an argument could be made that the level of procedural protections the Board is required to provide may be lower now as a result of its function of “decision-maker" being replaced with recommendation-making functions through the amendments to section 52 of the $N E B$ Act, the Board remains a decision-maker for terms and conditions for certificated pipelines, as well as for the majority of the other regulatory applications received, including for international power line (IPL) certificate applications and for smaller pipeline and facility applications for which exemption orders are sought under section 58 of the NEB Act. It also continues to have many of the attributes of a court, including being a "court of record" and having the same powers with respect to witnesses and evidence as a court of superior jurisdiction, the ability to make rules respecting "the sittings" of the Board, the requirement 
In addition to there being a legal right to be heard, there is also recognition in the case law and treatises of a discretionary type of standing. ${ }^{11}$ A person may have information that a decision-maker needs or wants in order to make its decision, and, as a result, his or her participation may add value to, or assist a tribunal in making its decision. The Board, as an administrative tribunal and the master of its own procedure, ${ }^{12}$ has discretion to allow these people to participate.

\section{UNDERLYING FOUNDATION OF STANDING DECISIONS}

In addition to understanding the purpose of standing, it was also important to understand the legal foundation upon which the Participation Framework was built. The issue of standing has been widely considered by courts and tribunals. This has led to an abundance of case law and decisions that are often confusing and appear inconsistent. Despite this, there are some key concepts underlying standing decisions. The Board's Participation Framework was developed with these general concepts in mind.

The starting point for most standing decisions is to see what the enabling statute explicitly states about who may participate, as clear legislative provisions prevail over common law requirements. This is known as the "statutory standing test."

As noted above, the statutory standing test is outlined in section 55.2 of the NEB Act. ${ }^{13}$ There is no explicit statutory standing test for other types of applications under the NEB Act, apart from the test applicable to detailed route hearings. ${ }^{14}$

A comprehensive approach to standing must also look beyond the wording of statutory standing tests. The context, purpose, and objectives of the legislative scheme must also be considered. ${ }^{15}$ In Specter v. Nova Scotia (Minister of Fisheries and Aquaculture), the Court stated, “[i]t does not matter whether a statute uses the phrase, 'person aggrieved', 'person

that certain hearings be public, and the ability of decisions or orders to be made a rule, order, or decree of the Federal Court or of a superior court and to be enforced as such. Most of these attributes continue to apply to the Board when assessing pipeline certificate applications. As noted, section 55.2 of the NEB Act applies on its face to certificate applications (i.e. pipeline and IPL), and, as discussed in Part II.B.1, below, the Board has applied it to smaller facility applications. Considered en masse, the Board continues to be a quasi-judicial administrative tribunal when it is exercising the majority of its regulatory application assessment functions.

See e.g., Canada (Dir of Investigation) v Newfoundland Telephone Co, [1987] 2 SCR 466; Society of Composers, Authors and Music Publishers of Canada v Copyright Board (Can) (1993), 61 FTR 141 FCTD).

12 Recognized by the Supreme Court of Canada in Knight v Indian Head School Division No 19, [1990] 1 SCR 653 at 685 :

It must not be forgotten that every administrative body is the master of its own procedure and need not assume the trappings of a court. The object is not to import into administrative proceedings the rigidity of all the requirements of natural justice that must be observed by a court, but rather to allow administrative bodies to work out a system that is flexible, adapted to their needs and fair. As pointed out by de Smith (de Smith's Judicial Review of Administrative Action (4th ed. 1980), at p. 240), the aim is not to create "procedural perfection" but to achieve a certain balance between the need for fairness, efficiency and predictability of outcome.

13 Supra note 3. This section applies to applications made under section 52, 58 or 58.16 of the NEB Act. See Part II.B.1, below, for further discussion.

$14 \quad$ Ibid. Sections 34 to 39 of the NEB Act set out a standing test and the process for approving the detailed route of certificated pipelines. These sections also apply to smaller pipelines that have not been exempted from the requirement to file for approval of their detailed route, as well as international and interprovincial power lines that are to be constructed and located under federal law pursuant to section 58.27 of the Act. Irving Shipbuilding Inc v Canada (Attorney General), 2009 FCA 116, [2010] 2 FCR 488 at para 33. 
directly affected', or 'direct and personal interest'. What matters is the interpretation that is given to these phrases. This necessarily involves a textual, contextual, and purposive analysis of the applicable legislation." ${ }^{\text {16 }}$ Accordingly, the context and objectives of the NEB Act informed the Board's approach to standing.

The Board's purpose is to regulate pipelines, energy development, and trade in the Canadian public interest. As noted in the Board's Strategic Plan, ${ }^{17}$ the public interest is inclusive of all Canadians and refers to a balance of economic, environmental, and social considerations that change as society's values and preferences evolve over time. In carrying out its purpose under the NEB Act, the Board is mandated to make decisions or recommendations on specific projects applied for or on applications made to it. The "public interest" is an explicit statutory consideration for some matters (for example, Part III construction and operation authorization applications, and section 16.1 confidentiality applications), but not others (for example, Part IV toll and tariff applications).

Under the NEB Act, the Board was not given a broad policy-making role with respect to Canada's energy strategy, the development of Canada's resources, the exploitation of Canada's oil and gas, or Canada's environmental policy. Although the federal Crown has indicated that it will rely on the Board's processes to the extent possible to discharge its obligations for Aboriginal engagement and consultation with respect to a proposed project, the Board is not an agent of the Crown. ${ }^{18}$

The Board's role with respect to an application is to assess that application and either approve or deny it or, for pipeline certificate applications, to make a recommendation to the Governor-in-Council to approve or deny that application, potentially with conditions. In carrying out this function the Board acts as a quasi-judicial tribunal. ${ }^{19}$ The Participation Framework is informed by this non-policy, quasi-judicial, and project-specific assessment mandate.

Pursuant to section 24, the NEB Act requires the Board to hold “public hearings" for certain applications. ${ }^{20}$ This does not mean that the Board must hear from every member of the public who wishes to speak. In Attorney General of Manitoba v. National Energy Board, the Federal Court stated that the word "public" in the context of section 24 (then section 20) means that "every member of the public, subject to the qualification that such person has a demonstrable interest in the subject matter before the Board over and above the public generally, shall have the right to participate in a hearing." ${ }^{21}$ With the inclusion of a more restrictive standing test read into the $N E B$ Act, a person with a "demonstrable interest" must be either directly affected or have relevant information or expertise. eng.html>.

See e.g. Major Projects Management Office, "Project Agreement for the TransCanada Keystone XL Pipeline Project," online: Government of Canada <mpmo.gc.ca/projects/69>.

Quebec (Attorney General) v Canada (National Energy Board), [1994] 1 SCR 159.

Supra note 3.

[1974] 2 FCR 502 at 518 [Manitoba] [emphasis added]. 
The Jobs Act modified the NEB Act, adding time limits for certain applications and provisions relating to the conduct of expeditious proceedings. ${ }^{22}$ As a result, the Board is required to comply with these sections, as well as the standing section.

In addition to the words and purpose of a statute (and any relevant judicial consideration of the NEB Act or similar wording in other legislation), common law principles of natural justice also provided guidance to the Board. As noted above, these principles apply to the Board in the exercise of its quasi-judicial functions, such as application assessment.

Among other things, the principles of natural justice require that a person be given an adequate opportunity to be heard before a decision affecting their interests is made. Case law indicates that there still needs to be a sufficiently direct impact in order to trigger natural justice rights to participate. As noted by Justice Marceau in Canadian Transit Co v. Canada:

It is clear to me that mere interest in the eventual outcome of a proceeding before a tribunal, whether financial or otherwise, is not in itself sufficient to give an individual a right to participate therein. The demands of natural justice and procedural fairness certainly do not require so much and in any event it would be impossible in practice to go that far. In my judgment, to be among the interested parties that a tribunal ought to involve in a proceeding before it to satisfy the requirements of the audi alteram partem principle, an individual must be directly and necessarily affected by the decision to be made. His interest must not be merely indirect or contingent. $^{23}$

\section{THE CASE FOR CONSISTENCY OF APPROACH FOR STANDING ON All TYPES OF APPLICATIONS}

The Board has implemented a Participation Framework that is consistent for all applications, regardless of whether section 55.2 of the NEB Act applies. It has done so by establishing an analogous test with similar factors to consider for those applications under the NEB Act to which section 55.2 does not apply. The Board has issued public guidance documents that reflect its Participation Framework. ${ }^{24}$

To be clear, "consistency" does not mean consistency of outcome, but rather consistency in approach (that is, consistency on the test and factors used to make decisions on standing). The Board makes its decisions based on the facts and evidence before it in a particular case. Applying the factors in the tests requires an assessment of the particular facts in each case, and as a result, the outcomes will vary depending on the facts before the Board. Notwithstanding potentially different outcomes in different factual circumstances, the tests and factors applied are analogous and intended to be consistently applied.

$22 \quad$ Supra note 3, ss 11(4), 52(4), 58(5), 58.16(5); Jobs Act, supra note 5.

23 [1989] 3 FCR 611 at 614 (FCA). Also adopted in 2127423 Manitoba Ltd v Unicity Taxi Ltd, 2012 MBCA 75, 280 Man R (2d) 292 at para 23.

24 See "Participation \& Lands," online: NEB <www.neb-one.gc.ca/prtcptn/index-eng.html>; “Applying to Participate in a Hearing,” online: NEB < www.neb-one.gc.ca/prtcptn/hrng/ppblngprtcpt-eng.html> . See also the two guidance documents linked there: "Section 55.2 Guidance - Participation in a Facilities Hearing,” online: NEB < www.neb-one.gc.ca/prtcptn/hrng/prtcptnthrhrnggdncs52_2-eng.html> ["Section 55.2 Guidance”]; "Non-Statutory Guidance — Participation in Other Hearings,” online: NEB <www.neb-one.gc.ca/prtcptn/hrng/prtcptnthrhrnggdnc-eng.html> [“Non-Statutory Guidance”]. 
Under section 55.2, there are two ways to obtain standing. First, a person can be directly affected by a project (reflecting a natural justice right to participate). ${ }^{25}$ In that circumstance, section 55.2 requires that the Board consider that person's representations. Second, a person could have relevant information or relevant expertise. In that circumstance, the Board may grant standing on a discretionary basis. A person can fall into either or both categories.

There are sections of the NEB Act where there is no legislated standing test. In those sections, as the Board is master of its own procedure, the Board has provided guiding principles for its standing determinations. Given the goal and foundations for granting standing, it is not unexpected that an analogous test and considerations would apply.

The Board determined that standing will be granted to those people who, through the application of the principles of natural justice, have a right to participate because they are sufficiently impacted.

Standing may also be granted to those people whose participation the Board finds would assist or add value to the decision-making process. While there is no legislative recognition in the NEB Act or common law (in other words, natural justice) requirement for this second category of standing for most ${ }^{26}$ of the other application sections in the $N E B$ Act, the Board as a quasi-judicial tribunal which is master of its own procedure has established this second category for the non-legislated standing test. These two categories within the non-legislated general standing test are intended to reflect the typical reasons standing is granted, and to mirror, to a great extent, the categories in section 55.2. Similar to the test in section 55.2, a person can fall into either or both of these categories.

In addition to aligning with the reasons for which standing is granted, pursuing consistency and simplicity on all matters related to the issue of standing makes it easier for people to understand the Board and its processes. A consistent and sound test for standing using relevant and consistent factors sets clear expectations for regulated companies and the public, allowing potential participants to justify why they should participate, and it also allows challengers the opportunity to articulate why those people should not participate.

26 The exception being for detailed route hearings, where the NEB Act indicates that the Board has discretion to allow "any other interested persons" to participate once an oral hearing is triggered: supra note 3 . 


\section{B. The Statutory Standing TeSt - Section 55.2}

\section{Application OF SECTION 55.2 TO \\ SECTION 58 EXEMPTION ORDER APPLICATIONS}

The Board has applied section 55.2 to applications for exemptions under section 58 of the NEB Act. ${ }^{27}$ It has done so for two main reasons.

First, section 55.2 is prefaced with the words "[o]n an application for a certificate.”"28 Applications under section 58 seek exemption from certain requirements that apply to major pipeline projects, provided the pipeline for which exemption is being sought is $40 \mathrm{~km}$ or shorter in length. ${ }^{29}$ Section 58 allows the Board the discretion to exempt a project proponent from, among other things, having to hold a valid certificate ${ }^{30}$ prior to operating a pipeline. This is not a mandatory exemption; if the Board determines that a project proponent requires a certificate, it could deny this exemption or any of the other exemptions requested, and has done so in the past. ${ }^{31}$ If a section 58 exemption from the requirement in paragraph 30(1)(a) to hold a certificate is not granted, the outcome is not necessarily a denial of the application. Instead, it could result in the issuance of a certificate rather than an exemption order. ${ }^{32}$ Both certificate applications and applications for exemption orders are subject to a maximum time limit of 15 months. $^{33}$

Second, paragraph 6(2.2)(d) of the NEB Act provides the Chair of the Board with the authority, among other things, to specify the manner in which the section 55.2 test is to be applied in respect of the application if a time limit imposed under section 52, 58, or 58.16 is not likely to be met. ${ }^{34}$ If section 55.2 did not apply to section 58 exemption applications, the portion of paragraph 6(2.2) giving the Chair authority to specify the manner in which section 55.2 is to apply if a section 58 time limit is at risk would be meaningless.

A principle of statutory interpretation called the presumption of coherence holds that legislation is presumed not to contain contradictions or inconsistencies and should be interpreted to avoid such results. ${ }^{35}$ Principles of statutory interpretation also confirm that a "section or enactment must be construed as a whole; each portion throwing light, if need be, on the rest." ${ }^{36}$ Furthermore, there is a presumption that the provisions of legislation are meant

\footnotetext{
Manitoba, supra note 21.

Supra note 3, s 55.2.

Ibid, s 58.

This requirement is found under paragraph 30(1)(a) of the NEB Act, ibid.

Most frequently, the Board has denied requested exemptions from the leave to open provisions, paragraph 30(1)(b) and section 47. See for example, the Board's decision in Kinder Morgan Cochin ULC Reversal Project (13 June 2013), A52393, online: NEB <www.neb-one.gc.ca>. For a discussion of the discretionary nature of section 58 exemptions, see Chapter 6 of the Board's Reasons for Decision in Enbridge Pipelines Inc. Terrace Expansion Program Phase II, (May 2001) OH-1-2000, online: NEB $<$ www.neb-one.gc.ca>.

32 In light of the other 2012 legislative amendments, refusing exemption from section 30(1)(a) but not denying the application itself would result in a pipeline application being decided upon by the Governor in Council rather than the Board, pursuant to section 54: supra note 3.

Ibid, ss 52(4), 58(5).

Ibid, ss 6(2.2)(d), 52, 55.2, 58, 58.16.

Ruth Sullivan, Sullivan on the Construction of Statutes, 5th ed (Markham: LexisNexis Canada, 2008) at 325 .

Ibid at 359.
} 
to work together as parts of a functioning whole. The parts are presumed to fit together logically to form a rational, internally consistent framework. ${ }^{37}$

For these reasons, the Board has applied the section 55.2 test to both certificate and exemption order applications. This gives effect to both provisions and is consistent with the exemptions in section 58 being discretionary.

\section{SECTION 55.2 TEST AND FACTORS}

Having considered the foundations of standing and recognizing the desire for consistency in approach, the Board turned to expanding upon the Participation Framework. In section 55.2, the Board was given the test, but there was still room for providing guidance on some of the terms within the legislated test.

a. "Directly Affected"

It is well established that the legislative evolution of provisions may be relied on to assist statutory interpretation. ${ }^{38}$ The shift away from "interested person" (formerly section 53), to any person who is "directly affected" or has "relevant information or expertise" (section 55.2) and the inclusion of the qualifier "directly" arguably indicates Parliament's intention to raise the threshold for obtaining standing for certain applications. ${ }^{39}$

The term "directly affected" is not defined in the NEB Act, so one must look to the case law and commentary..$^{40}$ In Canadian Union of Public Employees, Local 30 v. WMI Waste Management of Canada Inc., the Alberta Court of Appeal interpreted "directly affected" to mean a personal and individual interest as distinct from a general interest which pertains to the whole community. ${ }^{41}$ However, other decisions have found that this distinction is not required. ${ }^{42}$

In Friends of the Athabasca Environmental Association v. Alberta Public Health Advisory and Appeal Board, the Alberta Court of Appeal stated:

\section{Ibid at 325 .}

Ibid at 577.

Supra note 4, s 53; supra note 3, s 55.2.

For example, the meaning of the phrase "directly affected" was the central focus of the standing analysis in Dr Martha Kostuch v Director, Air and Water Approvals Division, Alberta Environmental Protection (23 August 1995), 94-017, online: Alberta Environmental Appeals Board <www.eab.gov.ab.ca>, aff'd Kostuch v Environmental Appeal Board (Alta) (1996), 182 AR 384 (QB) [Kostuch].

41 (1996), 178 AR 297 (CA). This interpretation of "directly affected" relied upon the Privy Council's interpretation of the phrase in Re Endowed Schools Act, [1898] AC 477 (PC). It was also adopted by the Ontario Court of Appeal in Corp of Canadian Civil Liberties Assn v Ontario (Civilian Comm on Police Services) (2006), 86 OR (3d) 798 (CA). Similarly, in Canada (Director of Investigation and Research, Competition Act) v Air Canada, [1992] CCTD No 24 (QL) [Air Canada], the Canada Competition Tribunal indicated that "directly affected" did not include a person who may have strong views on the outcome of a case, but could demonstrate no direct effect on him that was different from the public at large.

42 In Kelly v Energy Resources Conservation Board (Alta), 2011 ABCA 325, 515 AR 201 [Kelly], the Court determined that the appellants were not required to establish that they may be affected in a different way or to a greater degree than members of the general public. Also see Court v Environmental Appeal Board (Alta), 2003 ABQB 456, 333 AR 308 [Court]. 
The use of the modifier "directly" with the word "affected" indicates an intent on the part of the Legislature to distinguish between persons directly affected and indirectly affected. An interpretation that would include any person who has a genuine interest would render the word "directly" meaningless, thus violating fundamental principles of statutory interpretation. ${ }^{43}$

There are different variations of the statutory standing test among regulatory tribunals. Standing before the Alberta Environmental Appeals Board is based on whether a person is "directly affected" by the Director's decision. ${ }^{44}$ The reference to the word "affects" in relation to a person seeking leave to intervene has been interpreted by the federal Competition Tribunal to mean "directly affected." 45 Participation in a hearing before the Alberta Utilities Commission depends on whether the decision on an application "may directly and adversely affect the rights of a person."46 If the Alberta Energy Regulator conducts a hearing, "a person who may be directly and adversely affected by the application" is entitled to be heard at the hearing. ${ }^{47}$ Case law reveals that there is no specific checklist of requirements for obtaining standing. ${ }^{48}$ Rather, standing must be determined on a case-by-case basis, taking into account the particular facts and circumstances of each case.

The "directly affected" language used in the NEB Act is imprecise; therefore, instead of setting out a strict interpretation of "directly affected" that might be inflexible in its application, the Board developed relevant factors it would take into account when applying the standing test. As noted in the Board's guidance document "Section 55.2 Guidance Participation in a Facilities Hearing," the factors the Board may consider are:

1. The nature of the person's interest.

- Whether a person has a specific and detailed interest, rather than a general public interest.

- $\quad$ Examples of interests that could support participation are:

○ commercial, property or other financial interest (including employment);

○ personal use and occupancy of land and resources; or

○ use of land and resources for traditional Aboriginal purposes.

2. Whether the granting or refusing of a project application causes a direct effect on the person's interest.

(1996), 181 AR 81 at para 10 (CA). Environmental Protection and Enhancement Act, RSA 2000, c E-12, s 91(1).

Competition Tribunal Act, RSC 1985, c 19 (2d Supp), s 9(3). Also see Air Canada, supra note 41. Alberta Utilities Commission Act, SA 2007, c A-37.2, s 9(2). Similarly, standing before the former Alberta Energy Resources Conservation Board was based on whether its decision on an application may "directly and adversely affect the rights of a person": Energy Resources Conservation Act, RSA 2000, c E-10, s 26(2), as replaced by Responsible Energy Development Act, SA 2012, c R-17.3 [REDA]. REDA, ibid, s 34(3).

Kostuch, supra note 40 at para 25; Court, supra note 42; Dene Tha' First Nation v Energy and Utilities Board (Alta), 2005 ABCA 68, 363 AR 234 at para 10; Kelly, supra note 42; Specter, supra note 16 at paras 61-62; Canada (Commissioner of Competition) v Direct Energy Marketing Ltd, [2013] CCTD No 16 at para 3 (QL); Re Royal Commission on the Northern Environment (1983), 144 DLR (3d) 416 at 419 (Ont H Ct J). 
- The degree of connection between the project and the interest.

- The likelihood and severity of harm a person is exposed to.

- The frequency and duration of a person's use of the area near the project. ${ }^{49}$

These factors are to be considered conjunctively — there needs to be both an interest and a degree of causation between the decision to be made and the effect on that interest. Furthermore, these factors reflect the case law, and are consistent with the language, purpose, and context of the NEB Act and principles of natural justice.

\section{b. Person with "Relevant Information"}

Relevant information is not defined in the NEB Act. Generally, information would be relevant if it relates to issues to be determined in the proceeding. Often, those issues are set out in a List of Issues attached to a Hearing Order issued by the Board. The issues to be determined in a proceeding are tied closely to the Board's mandate, as the Board is a creature of statute and can only exercise the jurisdiction, powers, and authorities granted to it (explicitly or implicitly) by its enabling statute and other statutes that grant the authority. In its guidance document, the Board indicated that it may consider these factors when deciding if a person has relevant information:

- $\quad$ the source of the person's knowledge (for example, local, regional or Aboriginal);

- the extent to which the information is within the project scope and related to the list of issues; and

- $\quad$ how much value the information will add to the Board's decision or recommendation. ${ }^{50}$

\section{c. Person with "Relevant Expertise”}

Before a court, the test for admitting expert opinion evidence is based on four criteria: (1) the evidence is relevant to some issue in the case; (2) the evidence is necessary to assist the trier of fact; (3) the evidence does not violate an exclusionary rule; and (4) the witness is a properly qualified expert. ${ }^{51}$ An expert is a person who possesses special knowledge and experience going beyond that of the trier of fact. ${ }^{52}$

Although the Board is not bound by the above considerations, they provided a starting point when identifying factors it would consider when looking at "relevant expertise.” In its guidance document, the Board indicated that it may consider these factors when deciding if a person has relevant expertise:

- $\quad$ the person's qualifications (for example, the person has specialist knowledge and experience);

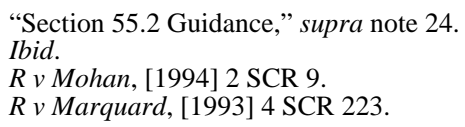


- the extent to which the person's expertise is within the project scope and related to the list of issues; and

- $\quad$ how much value the information will add to the Board's decision or recommendation. ${ }^{53}$

There will be times when it is clear that the information a person seeking standing wishes to contribute will not be helpful to the Board (for example, if the information sought to be tendered is not relevant to the issues to be determined). In those cases, the Board can exercise its discretion to deny standing (assuming the person is not also someone who is directly affected). There also may be instances where the Board already has the requisite expertise in a certain area, and may deny standing if additional assistance is not needed.

\section{NON-LEgISLATED TEST - WHAT TEST SHOULD BE APPlied fOr All Other APPlications?}

Having considered the test in section 55.2 and developed guidance for the factors the Board would look at when applying it, the Board then turned to developing guidance for the test and the factors for applications for which there was no existing legislative standing test.

The Board recognized that the purpose and the foundations of standing apply equally to other applications. Bearing in mind the goal of consistency and the purpose and foundations of standing, the Board developed a general standing test with concomitant factors and guidance. In order to avoid confusion and distinguish the two tests, the Board chose not to use the words "directly affected" and "relevant information or expertise" in relation to standing decisions for applications where section 55.2 of the NEB Act does not apply. This general test, with some exceptions, ${ }^{54}$ is intended to be used in all oral or written hearings involving applications to which section 55.2 does not apply.

\section{a. General Standing Test - The Test to Apply \\ When There is No Legislated Standing Test}

As discussed above, every administrative tribunal making a decision affecting the rights, privileges, or interests of an individual has a duty to be fair. This includes, subject to legislative restrictions, the right of participation for those who may be impacted by the tribunal's decision.

If a Board decision denying standing to a person outright or refusing participation as an intervenor were to be challenged, a Court would examine, among other things, whether the participation rights granted to the person ${ }^{55}$ were commensurate with the degree to which that person may be impacted by the tribunal's ultimate decision. Therefore, for the general standing test, the Board established a category to reflect the natural justice right to participate. This category is analogous to the first category of standing under section 55.2 of the NEB Act.

$53 \quad$ “Section 55.2 Guidance,” supra note 24.

For example, detailed route approval hearings would not follow this test, as there is a legislated standing test and process set out in sections 34 to 39: supra note 3.

Both the ability to participate as well as the level of participation. 
The Board also established a second category of standing. This category is analogous to the second category in section 55.2; namely, whether the person seeking to participate has information or expertise that will assist the Board in reaching its decision. While natural justice does not require that standing be granted to these people, discretion to allow for the participation of people whose knowledge would provide assistance to the Board in making its decision was desired.

Taken together, the Board established two means of obtaining standing where there is no statutory test:

1. the Board will allow a person to participate if a person's interest is sufficiently impacted by the Board's decision; and

2. the Board may allow a person to participate if that person's participation will assist the Board in making its decision. ${ }^{56}$

These categories are similar to the "directly affected" and "relevant information or expertise” categories stipulated in section 55.2 of the NEB Act. In addition, these categories are consistent with case law (although courts often use different terminology, depending on the facts and the legislation being considered). This is because the purpose of standing is ultimately the same: to satisfy the requirements of natural justice and to help the decisionmaker reach the best decision possible.

\section{b. Factors to Consider Under the General Standing Test \\ i. "Sufficiently Impacted"}

To be "sufficiently impacted," a person needs to demonstrate an interest that is impacted and that the decision on the application would cause a sufficient impact to that interest. As with section 55.2, both factors are required to be demonstrated.

In considering this first category of standing (that is, "sufficiently impacted") for all applications where there is no legislated standing test, the Board has provided guidance. The Board decides on a case-by-case basis who is sufficiently impacted. The Board will consider both of these factors when making this decision:

1. The nature of the person's interest.

- Whether a person has a specific and detailed interest, rather than a general public interest.

- Examples of interests that could support participation, depending on the nature of the application, are:

○ commercial, property or other financial interest (including employment); 
○ personal use and occupancy of land and resources; or

○ use of land and resources for traditional Aboriginal purposes.

2. Whether the decision on the application causes a sufficient impact on the person's interest.

- Whether the person's interest relates to issues that are relevant to the hearing.

- The likelihood that the Board's decision will impact the person's interest.

- Whether the interest may be impacted to a sufficient degree. ${ }^{57}$

\section{ii. "Assistance to the Board"}

The second category of standing requires that a person demonstrate that the information he or she will contribute will add value or assist the Board in the decision it has to make. To add value or assist the Board, the information: (1) should be relevant to the issues to be decided, be needed or wanted by the Board (that is, not duplicative of information already before the Board or already within the Board's expertise); and (2) be provided by someone who is qualified to provide this information (that is, who is credible).

For this second category, the Board considers, on the facts of each case, the following factors:

- The source of the person's knowledge (for example, local, regional, or Aboriginal);

- $\quad$ the person's qualifications (for example, the person has specialist knowledge and experience);

- the extent to which the information relates to the application; and

- $\quad$ how much the person's participation will add value to, or assist the Board in making, the Board's decision. ${ }^{58}$

These factors are purposely very similar to those in the Section 55.2 Guidance. Since the same principles underlie both standing tests, the result is a consistent and legally-defensible approach to standing.

\section{LeVel of Participation}

Neither the section 55.2 test or guidance nor the Board's general standing test or guidance dictate the level of participation that should be granted once standing has been obtained. Neither guarantees any particular procedural process for a person granted standing. For example, while the Board may be of the opinion that a person is "directly affected" by the application for a certificate to construct and operate a project, that does not translate into a 
specific procedural guarantee (that is, that they be granted the fullest possible participation rights). The Board is able to provide the process and participation rights it deems appropriate for a person to have his or her representations considered by the Board, provided the Board adheres to principles of natural justice and legislative requirements. ${ }^{59}$

There are several ways in which someone can be allowed to participate that would allow the Board to meet natural justice and legislative requirements without the need to hold an oral hearing for all applications and grant full intervenor status to everyone. What is fair in a given case will depend on the circumstances. An oral hearing (or, more typically at the Board, a hearing conducted substantially in writing with a short oral portion) is not always necessary, ${ }^{60}$ nor is providing full intervenor status to everyone who requests it. However, if an important individual interest is at stake, more procedural rights are likely to be required in order to satisfy principles of natural justice. ${ }^{61}$ Thus, in addition to factoring into the Board's standing determinations, principles of natural justice also factor into its decisions on the level of participatory rights that should be made available to a person.

Part II of the National Energy Board's Rules of Practice and Procedure ${ }^{62}$ governs procedures for public hearings, although the Board may dispense with or vary these rules. ${ }^{63}$ Intervenors and letters of comment (sections 28 and 30) are the only referenced levels of participation in the Rules by which the Board may consider the representations of participants. ${ }^{64}$ Notwithstanding that the Rules only reference two levels, the Board has exercised its discretion in past facilities hearings to create additional levels of participation. In some hearings, there have been up to four levels of participation: (1) intervenor; (2) letter of comment; (3) Government Participant; ${ }^{65}$ and (4) oral statement maker. The use of oral statements was offered as an option in certain facilities application hearings in the last 10 years, while the Government Participant role was established in $2005 .{ }^{66}$ Additional variations are within the Board's discretion to create and use, pursuant to section 4 of the Rules, provided legislative requirements and natural justice principles are respected. ${ }^{67}$

The level of participation offered can be tailored to what the Board considers would best meet the needs of both the participants and the Board itself. Anything from a one-time

For example, in addition to applying the standing test and being subject to time limits for certain applications, the Board is required to deal with applications in a certain manner, pursuant to subsection 11(4) of the NEB Act, supra note 3: "Subject to subsections 6(2.1) and (2.2), all applications and proceedings before the Board are to be dealt with as expeditiously as the circumstances and considerations of fairness permit, but, in any case, within the time limit provided for under this Act, if there is one."

60 Sara Blake, Administrative Law in Canada, 5th ed (Markham: LexisNexis, 2011) at 12.

61 For example, in Islands Protection Society v Environmental Appeal Board (1986), 1 CELR (NS) 137 (BC SC), the Court decided that natural justice required a public hearing to be held with oral evidence and cross-examination due to the significance of the environmental issues and public importance of the pesticide spraying permits at issue.

62 National Energy Board Rules of Practice and Procedure, 1995, SOR/95-208 [Rules].

Ibid, s 4.

Ibid, ss 28, 30.

To obtain standing and level of participation as a Government Participant, the applicant must be a federal, provincial, or territorial government department or agency that has environmental assessment responsibilities. There are specific participation rights and responsibilities attached to this role. NEB, Regulatory Agenda 04-2005 (30 April 2005), online: Government of Canada <publications.gc.ca/ collections/collection/NE12-4-2005-4E.pdf>.

Additional levels have been experimented with in the past (e.g., Option 1 intervenor and Option 2 intervenor in the Sumas Energy 2, EH-1-2000 international power line hearing) with differing degrees of success: Sumas Energy 2, supra note 2. 
opportunity to provide comments in writing at some point during the application assessment process (for example, letter of comment) to full participation through the written and oral (if any) portions of a hearing (for example, intervenor) may be available. The Board also has the ability to craft other levels of participation and may decide to offer these other levels for any particular hearing. For example, if the Board knows that a person has relevant information or expertise but is not able to participate in writing, the Board may allow that person to participate orally. If it appears that the person will be providing technical information and wishes to test the technical evidence of another party's experts, the Board may decide to allow that person to participate as an intervenor, who is able to file written evidence and both cross-examine and be cross-examined by others. The testing may occur either in writing through one or more information request process steps (similar to written interrogatories) or, if there is an oral portion of the hearing, during cross-examination of parties adverse in interest.

\section{E. Burden of Proof}

In the context of standing applications and decisions, the onus or "burden of proof" is on the person applying for standing. ${ }^{68}$ A person requesting participation should describe his or her interest and purpose for participating with sufficient particularity to enable other parties to make representations and to aid the tribunal in deciding whether to grant status and to define the scope of participation. ${ }^{69}$ The case law has also indicated that once the applicant for standing has established certain facts that demonstrate the applicable standing test is met, the evidentiary burden then shifts to the objecting party, if any, to disprove those facts. ${ }^{70}$

Sufficient evidence must be presented by the person seeking to participate in order to discharge his or her burden of proof. The question of whether this burden has been discharged is evaluated against the civil standard of a "balance of probabilities," as opposed to the criminal standard of "beyond a reasonable doubt." ${ }^{\text {"71 }}$ Although the balance of probabilities is a lower threshold than that of beyond a reasonable doubt, persuasive evidence is still required to meet this burden. This can be as simple as completely filling out a standard application form that requires the person seeking to participate to identify clearly why he or she should be allowed to participate. As the applicant bears the burden of proof, an improperly completed or incomplete form could result in that person not being granted participation rights.

Certain case law suggests that the potential participant need not prove that he or she will in fact be impacted by the approved project. He or she need only prove a potential or reasonable probability of an impact. ${ }^{72}$ While some jurisprudence suggests that the impact does not even have to be likely, ${ }^{73}$ other decisions assert that the impact should be actual and imminent and not speculative. ${ }^{74}$ This impact must be within reason, plausible, and relevant

Kostuch, supra note 40; Petro-Canada Oil Sands Inc (27 March 2008), 2008-024, online: ERCB $<$ www.aer.ca $>$ at 4 (prehearing meeting application to construct and operate the Sturgeon upgrader). Blake, supra note 60 at 29.

Kelly, supra note 42 at paras $43-44$.

Court, supra note 42 at para 69.

Ibid at para 71.

Kelly, supra note 42 at para 26.

Kostuch, supra note 40. 
to the Board's jurisdiction to be considered sufficient to grant standing. ${ }^{75}$ Despite the sometimes conflicting case law, the Board decided that "reasonable probability" was a fair and rational standard to apply. Accordingly, the Board considers whether the person seeking to participate has demonstrated, on a balance of probabilities, that there is a reasonable probability of an impact.

\section{IMPLEMENTATION OF THE BOARD'S PARTICIPATION FRAMEWORK}

\section{A. Guidance Documents}

Once the Board established its Participation Framework, it communicated its revised approach to participation to the public. The standing test and factors discussed above in Parts II.B and II.C were placed into guidance documents to clarify the Board's expectations. The Board's "Section 55.2 Guidance” and "Non-statutory Guidance” are publicly available on its website. ${ }^{76}$ Updated information about participation in hearings is also published ${ }^{77}$ by the Board and available online. ${ }^{78}$

\section{B. Application to Participate Form}

As discussed above, the burden of proof is borne by the party applying for standing. People who fail to demonstrate that they fall under at least one category of the standing test will not be granted standing. To gather the necessary information, the Board developed an Application to Participate Form (ATP Form) to replace its former Application for Intervenor Status, Letter of Comment Form, and Request to Make an Oral Statement Form.

The ATP Form is an interactive online form that can be saved to an account. It has userfriendly instructions and mandatory fields that must be completed before submission. ATP Forms are project-specific, but generally require information about the proposed participant's interest in the project or information her or she wishes to contribute, and how this relates to the list of issues established by the Board for the assessment of the project. Board Process Advisors provide the public with assistance on how to complete the ATP Form.

\section{Participation in Recent BoARd Proceedings}

The Board assesses applications to participate on a case-by-case basis and decides who is allowed to participate and at which level. Recent Board proceedings illustrate how participation has varied for different types of hearings and how the Participation Framework is being applied.

Dyrholm v Director, Central Region, Environmental Management, Alberta Environment (19 November 2009), 09-002-003-D, online: Alberta Environmental Appeals Board <www.eab.gov.ab.ca> at para 55. Supra note 24.

See e.g. NEB, Hearing Process Handbook: A Guide to NEB Hearings (Calgary: NEB, 2013). See e.g. supra note 24. 


\section{EnBridge EdMONTON TO HARdisty PiPELINE PROJECT - OH-001-2013}

The Enbridge Edmonton to Hardisty Pipeline Project included the construction and operation of an approximately 182-km new crude oil pipeline that would be contiguous to an existing pipeline right-of-way and other existing linear disturbances for approximately 91.3 percent of its length. The Board received eight ATP Forms. The Board granted standing to all eight applicants at their requested levels of participation. ${ }^{79}$

\section{ENBRIDGE LINE 9B REVERSAL AND LINE 9 CAPACITY EXPANSION PROJECT - OH-002-2013}

The OH-002-2013 proceeding involved a proposal to reverse a 639-km segment of Line 9 between North Westover, Ontario and Montreal, Quebec, with an additional request to increase the capacity of the entire Line 9 from approximately 240,000 barrels per day (bpd) to approximately 300,000 bpd. One hundred seventy-seven ATP Forms were filed, and the Board granted standing to 158 people at the level of participation requested. Eleven people were granted standing at a reduced level of participation (that is, they requested intervenor status and were instead granted the opportunity to submit a letter of comment). The Board found that these people were not directly affected, yet granted standing to them in order to hear local information relevant to the project. ${ }^{80}$ Eight applicants were denied standing. Two of these individuals submitted blank ATP Forms. The remainder provided insufficient detail in their forms; for example, the Board found that they only demonstrated a general public interest in the project or asserted areas of expertise that were not relevant to the project.

\section{SET-AsidE AND COLLECTION MECHANISMS — MH-001-2013}

The Board held the MH-001-2013 proceeding to consider the mechanisms proposed by federally-regulated pipeline companies to set aside and collect funds to cover the cost of future pipeline abandonment projects. Twenty-three ATP Forms were filed and the Board granted 21 standing at the level requested. ${ }^{81}$ The Canadian Association of Petroleum Producers (CAPP) and the Canadian Association of Energy and Pipeline Landowner Associations (CAEPLA) were denied standing. CAPP did not file an ATP Form. CAEPLA's ATP Form indicated that it "represents landowners across Canada who are directly affected by the Board's decision,” but did not provide any additional information in support of this assertion. ${ }^{82}$ The Board indicated that CAPP and CAEPLA could reapply to participate. CAPP subsequently reapplied and was granted intervenor status.

NEB, National Energy Board Report: In the Matter of Enbridge Pipelines Inc, OH-001-2013, January 2014, (Calgary: NEB, 2013), online: NEB <www.neb-one.gc.ca> at 5.

NEB, Enbridge Pipelines Inc (22 May 2013), OH-002-2013 (Procedural Update No 2), online: NEB $<$ www.neb-one.gc.ca> [Enbridge Pipelines].

Letter from NEB (14 August 2013) (Hearing Order MH-001-2013, Procedural Update No 1: List of Participants and Updated Timetable of Events), online: NEB < www.neb-one.gc.ca $>$.

Set-aside and Collection Mechanism Applications (25 July 2013), OF-AF-SAC 01 (Application to Participate, Deborah McVicar), online: NEB <https://docs.neb-one.gc.ca/ll-eng/llisapi.dll/fetch/2000/ 90463/782060/927998/972583/977551/A3J4Q0_-_Application_to_Participate.pdf?nodeid= $977810 \&$ vernum $=-2>$. 


\section{NOVA INTEGRATION ASSET TRANSFER APPLICATION}

NOVA Gas Transmission Ltd. (NGTL) filed an application with the Board requesting approval for the acquisition of certain assets currently owned by ATCO Gas and Pipelines Ltd. (ATCO) and the sale by NGTL of certain assets currently forming part of the NGTL System to ATCO. There is no new construction involved in this application. The Board received nine ATP Forms, of which eight requested intervenor status and one requested commenter status. The Board granted all nine applicants standing at their requested level of participation. ${ }^{83}$

\section{Trans Mountain EXPANSION PROJECT — OH-001-2014}

The Trans Mountain Expansion Project is a proposal to expand the existing Trans Mountain pipeline system between Edmonton, Alberta and Burnaby, British Columbia. The proposed project would include approximately $987 \mathrm{~km}$ of new pipeline, new and modified facilities, such as pump stations and tanks, and the reactivation of $193 \mathrm{~km}$ of existing pipeline. The proposal also includes an expansion of the Westridge Marine Terminal.

The Board set deadlines for ATP Forms to be filed, Trans Mountain Pipeline ULC (Trans Mountain) to comment on ATP Forms, and potential participants who received comments about their ATP Form to reply to Trans Mountain's comments. The Board received 2,118 ATP Forms. Trans Mountain filed general comments about how the Board should apply the standing test, but took no position on any of the specific applications submitted. Several potential participants responded with additional comments on how the Board should approach standing and participation.

Of the 2,118 ATP Forms reviewed by the Board:

- 400 requested intervenor status and [were] granted intervenor status;

- $\quad 798$ requested commenter status and [were] granted commenter status;

- $\quad 452$ requested intervenor status and [were] granted commenter status; and

- 468 [were] denied participation. ${ }^{84}$

Certain people seeking participation did not receive their requested level of participation because the Board found that the intervenor method of participation was not appropriate or necessary for the concern raised. For instance, for concerns regarding temporary effects or the effects of accidents or malfunctions, the Board determined in some cases that a letter of comment provided the best means for a participant to have his or her representations considered. Similarly, the Board decided that some relevant information and expertise put

83 Letter from NEB (2 April 2014) (Nova Gas Transmission Ltd, Integration Asset Transfer Project, List of Participants), online: NEB <www.neb-one.gc.ca>.

84 Letter from NEB (2 April 2014) (Hearing Order OH-001-2014, Trans Mountain Pipeline ULC, Application for the Trans Mountain Expansion Project, Ruling on Participation), online: NEB $<$ www/neb-one.gc.ca $>$. 
forward in ATP Forms could most efficiently and effectively be gathered through letters of comment.

The Board denied standing to persons who did not demonstrate to the Board's satisfaction that they were either directly affected by the project, or were in possession of relevant information or expertise that will assist the Board in its assessment. Some matters raised within the ATP Forms related to issues outside of the Board's mandate or were related to issues that were not specific to the particular applicant or to the project. Some applicants lived vast distances away from the project or stated general concerns about pipelines or how a spill might affect a community as a whole. Other applicants referred only to effects from Chevron's facilities, which were not part of the project application. The Board also denied standing where the applicant stated only global support for pipelines or made general references to benefits. In certain cases, sufficient information was simply not provided and standing was denied.

\section{North MontNey ProJeCt - GH-001-2014}

The North Montney Project includes the construction and operation of approximately $305.9 \mathrm{~km}$ of pipeline in the Peace River Regional District, along with 15 new meter stations, and three new compressor stations. Of the 48 ATP Forms reviewed by the Board:

- 33 requested intervenor status and [were] granted intervenor status;

- 12 requested commenter status and [were] granted commenter status; and

- 3 requested intervenor status and [were] denied participation. ${ }^{85}$

Apache Canada Ltd. (Apache) was denied standing because it had only a broad interest in the project. Imperial Oil Resources (Imperial) and ExxonMobil Canada (ExxonMobil) were denied standing because they stated they would be impacted but did not provide specific details of the nature of potential impacts.

Apache, Imperial, and ExxonMobil subsequently requested reconsideration and provided the Board with additional information. The Board then determined that they were directly affected due to the nature of their business interests and granted them intervenor status. ${ }^{86}$

\section{COURT CHALlenges AND REVIEWS}

The Board's Participation Framework and rulings on who may participate may be challenged through applications for review under section 21 of the NEB Act, or through appeals and judicial reviews to the Federal Court of Appeal. For example, project proponents

85 Letter from NEB (17 April 2014) (Hearing Order GH-001-2014, NOVA Gas Transmission Ltd, Application for the North Montney Pipeline Project, Ruling No 2 - Participation), online: NEB $<$ www.neb-one.gc.ca $>$.

86 Letter from NEB (14 May 2014) (NOVA Gas Transmission Ltd - North Montney Project, Application under section 52, section 58 and Part IV of the NEB Act, Ruling No 4-Applications for Reconsideration of Standing Decisions), online: NEB <www.neb-one.gc.ca>. 
may argue that the Board is not applying its standing test with enough rigour, while those who have been denied standing may assert that the standing test is being applied too stringently.

\section{FOREST ETHICS ADVOCACY ASSOCIATION AND DONNA SINCLAIR V. THE NATIONAL ENERGY BOARD AND THE ATTORNEY GENERAL OF CANADA}

The first court challenge arose from the Board proceeding for the Enbridge Line 9B Reversal and Line 9 Capacity Expansion Project. On 13 August 2013, Forest Ethics Advocacy Association and Donna Sinclair filed a judicial review application against the Board and Attorney General of Canada. Ms. Sinclair was an individual denied standing by the Board. In her ATP Form, Sinclair asserted that she was either directly affected or in possession of relevant information or expertise based on her religious beliefs and her Canadian citizenship in general. The Board was of the view that this was only a general public interest in the project and also noted that Sinclair lived in North Bay, Ontario, which was not in the vicinity of the project. ${ }^{87}$ Sinclair was denied standing.

The judicial review application ${ }^{88}$ requested:

- A declaration that section 55.2 of the NEB Act is an unjustifiable infringement of section 2(b) of the Canadian Charter of Rights and Freedoms. ${ }^{89}$

- An order quashing the Board's decision to issue an ATP Form and its decision to condition participation in Board proceedings on the completion of the form.

- An injunction restraining the Board from making its recommendation to the Minister under section 52(1) of the NEB Act regarding the project until the Court disposed of the judicial review application.

- $\quad$ An order that the Board accept all letters of comment from groups and individuals who seek to participate in the Line 9B proceeding. The Board can then give each letter of comment whatever weight it thought appropriate.

- $\quad$ Any other remedies as counsel may advise and the Court may grant.

Forest Ethics Advocacy Association and Sinclair argued that section 55.2 grants the Board authority to screen out applicants based on arbitrary criteria, which violates their right to freedom of expression. They asserted that the Board could have considered all applications, accepted all letters of comment and then given each submission whatever weight it thought appropriate. They also alleged that the ATP Form creates a chilling effect on free speech.

$87 \quad$ Enbridge Pipelines, supra note 80.

$88 \quad$ Forest Ethics Advocacy Assn v National Energy Board (12 August 2013), Toronto T-B66-13 (FCA) (Notice of Application).

89 Part I of the Constitution Act, 1982, being Schedule B to the Canada Act 1982 (UK), 1982, c 11 [Charter]. Section 2(b) of the Charter guarantees the freedom of expression. 
Enbridge Pipelines Inc. (Enbridge) and Valero Energy Inc. (Valero) subsequently filed motions to be added as respondents to the judicial review proceeding, or alternatively, as intervenors. The Federal Court of Appeal issued its decision on these motions on 4 October 2013. ${ }^{90}$ Interestingly, the Court applied its own "directly affected” test under rule 303(1)(a) of the Federal Courts Rules ${ }^{91}$ to determine if Enbridge and Valero should have been respondents in the first place. The Court held that the question is "whether the relief sought in the application for judicial review will affect a party’s legal rights, impose legal obligations upon it, or prejudicially affect it in some direct way.",92

The Court decided that Enbridge should be added as a respondent because it was the project proponent and the prejudice is direct. If the relief sought in the judicial review were granted, it could lead to delays in Enbridge's project or even the rejection of its project application. In contrast, the Court dismissed Valero's motion even though Valero was an intervenor in the Board's proceedings. The project's approval would permit Valero to receive less expensive western Canadian crude oil and it had entered into a transportation services agreement with Enbridge. The Court recognized that Valero was in a commercial relationship with Enbridge and could suffer financially if the project is not approved. However, the Court held that this is the same position as any supplier of materials for the project and any workers involved in its construction; their interests, no doubt significant, are consequential or indirect, contingent on the proponent of the project getting its approval. ${ }^{93}$

This judicial review proceeding is ongoing. The Board will follow it closely as the Court's ultimate decision may assist the Board in refining its Participation Framework.

\section{TRANS MOUNTAIN EXPANSION PROJECT PARTICIPATION RULING REVIEW}

Board decisions on level of participation may also be challenged. After the Board issued its participation ruling for the Trans Mountain Expansion Project, Richard Pesklevits filed a motion on 13 April 2014, requesting that the Board grant him intervenor status rather than commenter status. Pesklevits stated that once the Board found him to be directly affected, his right to participate in the hearing crystallized and the Board lacked the discretion to deny him intervenor status. He contended that the Board exceeded its jurisdiction by placing an unreasonable limit on his right to make representations. Furthermore, Pesklevits claimed that he had a right to be heard before being denied intervenor status; the information in his ATP form was intended to establish standing and was, at best, only tangentially relevant to his level of participation.

The Board issued its ruling on 16 May 2014, denying Pesklevits' motion. ${ }^{94}$ The Board noted that section 55.2 does not specify how the Board is to hear from those representations it must consider. According to Sara Blake in Administrative Law in Canada, "[t]he right to

Forest Ethics Advocacy Association v National Energy Board, 2013 FCA 236, 450 NR 166 [Forest Ethics].

SOR/98-106.

Forest Ethics, supra note 90 at para 21.

Ibid at para 27.

Letter from NEB (16 May 2014) (Hearing Order OH-001-2014, Trans Mountain Pipeline ULC, Application for the Trans Mountain Expansion Project, Ruling No 15), online: NEB <www.nebone.gc.ca>. 
be heard is not a right to the most advantageous procedure.... It is only a right to have one's views heard and considered by the decision maker." 95 The Board indicated that there is no requirement to provide the requested or preferred method of participation found in the principles of natural justice. The Board stated that it must find a balance between the accommodation of the requests of those seeking to participate and the need for an efficient regulatory process, particularly in circumstances where there were over 1,000 requests for intervenor status.

In the same ruling, the Board also denied the Concerned Professional Engineers' 1 May 2014 request to be given intervenor status rather than commenter status. They had requested intervenor status based on having relevant information and expertise, but the Board found there was no legal requirement that it must hear from them in the manner they had requested.

\section{ConClusion}

As the Board continues to process larger and increasingly complex projects, it is important to ensure that the Board is able to hear from those directly affected (or sufficiently impacted) by a proposed project (or application) while meeting any legislated requirements, including time limits. The Board's Participation Framework was established to provide clear and consistent guidance to the public on how the Board implemented the legislative change to the NEB Act resulting from the Jobs Act. It provides transparency on how the Board hears from those who have a legal right to be heard, as well as those who have information that the Board may need or want to make its decision.

The Participation Framework is consistent with the case law on standing, the foundations and goals of participation, and the purpose and mandate of the National Energy Board, as well as legislative requirements and the principles of natural justice by which the Board is bound. The Participation Framework enables the Board to allow for meaningful public participation in fair and efficient proceedings as it carries out its mandate in the Canadian public interest. 